\title{
Growth and Tolerability of Healthy Term Infants Fed a New Formula Supplemented with DHA from Schizochytrium sp Microalgae

\author{
Mehta $\mathrm{P}^{1 *}$, Shepard $\mathrm{J}^{2}$, Rouse $\mathrm{K}^{3}$, Sullivan $\mathrm{T}^{4}$, McCarthy $\mathrm{D}^{5}$, Yurko-Mauro $\mathrm{K}^{5}$, Rooney $\mathrm{M}^{6}$, Schallon $\mathrm{D}^{6}$ and Secic $\mathbf{M}^{6}$
}

${ }^{1}$ Heartland Research Associates, LLC, Wichita, KS 67205, USA

${ }^{2}$ Ohio Pediatric Research Associations, Inc., Dayton, OH 45414, USA

${ }^{3}$ The Children's Clinic of Jonesboro, PA, Jonesboro, AR 72401, USA

${ }^{4}$ Norwich Pediatric Group, PC, Norwich, CT 06360, USA

${ }^{5}$ DSM Nutritional Products, Columbia, MD 21045, USA

${ }^{6}$ Accelovance Inc., Chicago, IL 60602, USA

\begin{abstract}
Objective: To evaluate growth and tolerability of infants fed a formula supplemented with docosahexaenoic acid (DHA) from a new strain of Schizochytrium sp (DHASCO $\left.{ }^{\circledR}-\mathrm{B}\right)$ microalgae.

Methods: Healthy term infants $(n=159)$ with weights $\geq 2500$ gram were randomized on or before $14^{\text {th }}$ day of life (DOL) to receive either DHASCO ${ }_{-}-\mathrm{B}$ or reference formula $\left(\mathrm{DHASCO}^{\circledR}\right)$ obtained from Crypthecodinium cohnii until DOL 120. Both formulas also contained arachidonic acid (ARA). Assessments included weight, length, weight/length ratio, head circumference, red blood cell (RBC) DHA and other fatty acids, metabolic panel, safety, and tolerance.

Results: The rate of mean daily weight gain $( \pm S D)$ at DOL 120 was not significantly different between the formulas, $29.1 \pm 5.92$ grams/day versus $29.9 \pm 7.40 \mathrm{grams} /$ day for $\mathrm{DHASCO}^{\circledR}$ and $\mathrm{DHASCO}^{\circledR} \mathrm{B}$, respectively and was equivalent $(90 \% \mathrm{Cl}:-2.94$ to $1.31 ; \mathrm{p}=0.553)$. There was no significant difference between formulas in actual weight gain over time, i.e. DOL $30,60,90$ and $120(p=0.252)$, including by gender. Other anthropometric variables were also not different between the 2 groups. RBC DHA levels at DOL 120 were bioequivalent between the formulas (ratio of geometric means was $96.85 \%$ ). There was no difference between formulas in any of the tolerance variables (watery stools, hard stools, gassiness, spitting up and fussiness), and no clinically meaningful difference in adverse events or laboratory values.

Conclusions: There was no significant difference in daily weight gain of healthy term infants fed a formula supplemented with DHA from Crypthecodinium cohnii versus the new strain of Schizochytrium sp microalgae. Overall weight gains were equivalent between the two formula groups. Further, RBC DHA levels were bioequivalent, and there was no difference in infant tolerability or parent satisfaction. In summary, growth, tolerability and safety profiles for the formulas were similar and typical for this age group.
\end{abstract}

Keywords: Term infants; Growth; Tolerability; Infant formula; Docosahexaenoic acid; DHA; Crypthecodinium cohnii; Schizochytrium Sp; Microalgae; Weight gain; Body length; Head circumference; Long chain polyunsaturated fatty acid; Red blood cell; RBC

\section{Introduction}

Docosahexaenoic acid (DHA) and arachidonic acid (ARA), omega-3 and omega-6 long-chain polyunsaturated fatty acids (LCPUFA), respectively, are commonly included in infant formulas. DHA is most abundant in the gray matter of the brain and in the retina of the eye where it is an important structural component of cellular membranes enhancing membrane structure and fluidity and has a modulatory role in cell signaling [1,2]. Clinical studies in human infants have provided evidence that DHA is essential for optimal brain and retinal development that translates into benefits in both visual and cognitive performance [3-9]. During neonatal life, there is a rapid accretion of both DHA and ARA in infant brain, DHA in retina and of ARA in the whole body [10].

It is important to provide an appropriate supply of preformed DHA throughout infancy as brain development and DHA accretion continue at a very rapid pace during the first 2 years of life [11]. Both DHA and ARA occur naturally in breast milk and their amounts depend on the maternal diet, with levels that vary worldwide from 0.1 to $1.4 \mathrm{wt} \%$ of total fatty acids for DHA and from 0.24 to $1.0 \mathrm{wt} \%$ for ARA [12]. The best estimates of worldwide mean breast-milk DHA and ARA concentrations (wt $\%$ of total fatty acids) are $0.32-0.40 \%$ for DHA and $0.47-0.56 \%$ for ARA [12]. In 2008, the World Health Organization (WHO) and the Food and Agriculture Organization of the United Nations (FAO) set recommendations for commercially available infant formulas at $0.20-0.36 \%$ for DHA and $0.40-0.60 \%$ for ARA of total fatty acids [13]. The highest contents of DHA and ARA are found in US commercial term formulas at levels $0.32 \%$ DHA and 0.64\% ARA [14].

In the U.S., the first commercially available DHA-containing oil for infant formulas was DHA single cell oil (DHASCO ${ }^{\circ}$ ) produced from the microalgae Crypthecodinium cohnii. DHASCO is generally recognized as safe (GRAS) for use in infant formulas at a maximum level of $1.25 \%$ (up to $0.5 \%$ for DHA alone) of the total dietary fat [15]. Two other DHA-containing algal oils derived from distinct algal strains of Schizochytrium sp. (DHASCO-S ${ }^{\circledR}$ and DHA-O ${ }^{\circledR}$ ) are GRAS for use in food and dietary supplements [16,17]. Recently, a

*Corresponding author: Mehta P, Heartland Research Associates, LLC, Wichita, KS 67205, USA, Tel: +316-689-6635; E-mail: pcm@heartlandresearch.com

Received April 25, 2016; Accepted May 26, 2016; Published June 06, 2016

Citation: Mehta P, Shepard J, Rouse K, Sullivan T, McCarthy D, et al. (2016) Growth and Tolerability of Healthy Term Infants Fed a New Formula Supplemented with DHA from Schizochytrium sp Microalgae. J Vasc Med Surg 4: 267. doi:10.4172/2329-6925.1000267

Copyright: ( 2016 Mehta P, et al. This is an open-access article distributed under the terms of the Creative Commons Attribution License, which permits unrestricted use, distribution, and reproduction in any medium, provided the original author and source are credited. 
new DHA-rich oil was obtained from a different wild-type strain of Schizochytrium sp., herein named DHASCO- ${ }^{\circledR}$. This oil is distinct from other algal oils in composition: it contains a minimum $40 \%$ DHA and up to $10 \%$ eicosapentaenoic acid (EPA) with a minor amount of docosapentaenoic acid (DPA). DHASCO- $\mathrm{B}^{\circledR}$ is intended for use in preterm and term infant formulas and follow-on formulas. DHASCO-B is a triacylglycerol, similar to the form of DHA found in breast milk. In July 2013, an independent panel of experts determined DHASCO ${ }^{\circledR}$-B to be GRAS (with maximum $0.5 \%$ of fat as DHA in infant formula) as acknowledged by FDA Office of Food Additive Safety, Center for Food Safety and Applied Nutrition in June 2015 [18].

This 120-day clinical study compared the growth and tolerance of healthy term infants fed formula containing DHA from DHASCO ${ }^{\circledR}-\mathrm{B}$ as $0.32 \%$ of total fatty acids versus infants fed a similar reference formula containing DHA from DHASCO ${ }^{\circ}$ as $0.32 \%$ of total fatty acids. There were no other changes in formula composition, including use of 0.64\% ARA in both formulas derived as a single cell oil (ARASCO ${ }^{\circledR}$ ) from the soil fungus Mortierella alpina. The primary objective was to determine whether weight gain and tolerability of healthy term infants fed a commercially available term infant formula supplemented with DHASCO ${ }^{\circledR}$ was similar to that of infants fed the same formula supplemented with a new product, $\mathrm{DHASCO}^{\mathbb{B}}-\mathrm{B}$. A secondary objective was to determine bioequivalence between the formulas in red blood cell DHA levels, an indicator of brain levels [19].

\section{Methods}

This study was designed as a randomized, double-blinded, activecontrolled, parallel two-group trial conducted at 12 U.S. clinical sites. The study design was consistent with guidelines detailed in the WHO Child Growth Standards [20]. The protocol and informed consent (IC) were approved by Chesapeake Institutional Review Board (Columbia, MD) and New England Institutional Review Board (Newton, MA) and underwent a revision to change the age of parents from $\geq 21$ years to a minimum of 18 years and to increase enrollment from 144 to approximately 159 infants. Overall study duration was approximately 14 months. The study trial was registered with Clinicaltrials.gov (NCT02144402).

\section{Study population}

Healthy term infants $(n=159)$ with weights $\geq 2500$ gram were stratified by gender and randomized on or before $14^{\text {th }}$ day of life (DOL) to receive either $\mathrm{DHASCO}^{\circ}$ or $\mathrm{DHASCO}^{\circ}$-B formula until DOL 120. Parents and the study site investigators and staff as well as the clinical research organization and trial sponsor were blinded regarding the study formula to which individual subjects were assigned.

Infants (parents) had to meet all of the following inclusion criteria to qualify for entry into the study: full term (gestational age 37 to 42 weeks), birth weight $\geq 2500$ grams, healthy singleton infant $\leq 14$ days, parent (minimum 18 years of age) provided consent on behalf of the infant, parent confirmed their intention to feed their infant the assigned study formula as the sole source of nutrition for the duration of the study unless instructed otherwise by their healthcare professional, and parent voluntarily signed and dated an IC document. Infants (parents) who met any of the following exclusion criteria did not qualify for entry into the study: congenital malformation or genetic disorder that could interfere with normal growth and development, other metabolic anomalies, maternal infectious diseases, alcoholism or substance abuse, mothers who had gestational diabetes and /or were receiving insulin during pregnancy, any other adverse maternal, fetal or infant medical history with potential to affect tolerance, growth, and/or development, and participation in another clinical study.

\section{Interventions}

At enrollment, eligible newborns were randomized 1:1 to investigational $\mathrm{DHASCO}^{\circledR}-\mathrm{B}$ or reference $\mathrm{DHASCO}^{\circledR}$ formula and were stratified by gender into block sizes of four utilizing an interactive web response system (IWRS). Infants were fed either the investigational or reference formula. Both formulas contained DHA as $0.32 \%$ of the total fatty acids and $0.64 \%$ ARA of the total fatty acid content. Compositions of the two formulas are detailed in Table 1. Both study products were in the form of a cow's milk-based infant formula packaged in ready-tofeed (RTF) liquid formulation in 8 ounce bottles (PBM Nutritionals, a Perrigo Company, Charlottesville, VA). In the DHASCO ${ }^{\circledR}-\mathrm{B}$ formula, the DHA source was a novel micro algal oil from a new strain of Schizochytrium sp. and, in DHASCO ${ }^{\circledR}$, the source was from commercially available algal oil derived from Crypthecodinium cohnii (supplied by DSM Nutritional Products, Columbia, MD). ARA in both formulas was derived as a single cell oil (ARASCO ${ }^{\circledR}$ ) from the soil fungus Mortierella alpine (DSM Nutritional Products). Both

\begin{tabular}{|c|c|c|c|}
\hline & DHASCO $®$ & DHASCO®-B & UNITS \\
\hline \multicolumn{4}{|l|}{ Proximate Nutrients } \\
\hline Arachidonic Acid & 230 & 240 & MG/L \\
\hline Carbohydrate By Difference Liquids & 7.2 & 7.2 & $\%$ W/W \\
\hline Docosahexaenoic Acid & 120 & 130 & MG/L \\
\hline Fat & 3.6 & 3.56 & $\% \mathrm{~W} / \mathrm{W}$ \\
\hline Linoleic Acid & 6330 & 6450 & MG/L \\
\hline Linoleic Acid per $100 \mathrm{KCAL}$ & 0.86 & 0.86 & GM \\
\hline Linolenic Acid per $100 \mathrm{KCAL}$ & 0.077 & 0.077 & GM \\
\hline Protein & 1.46 & 1.46 & $\% \mathrm{~W} / \mathrm{W}$ \\
\hline \multicolumn{4}{|l|}{ Vitamins and Micro-Nutrients } \\
\hline Ascorbic Acid & 164 & 181 & MG/L \\
\hline Biotin & 84 & 69 & MCG/L \\
\hline Choline & 230 & 208 & MG/L \\
\hline Cyanocobalamin & 6.9 & 7.1 & MCG/L \\
\hline Folic Acid & 199 & 186 & MCG/L \\
\hline Inositol & 66 & 66 & MG/L \\
\hline Niacin & 11917 & 11646 & MCG/L \\
\hline Pantothenic Acid & 8600 & 8300 & MCG/L \\
\hline Pyridoxine & 776 & 755 & MCG/L \\
\hline Riboflavin & 1917 & 1810 & MCG/L \\
\hline Thiamine & 1313 & 1282 & MCG/L \\
\hline Vitamin A & 2844 & 2865 & IU/L \\
\hline Vitamin D3 & 557 & 605 & IU/L \\
\hline Vitamin E & 21 & 21 & IU/L \\
\hline Vitamin $\mathrm{K}$ & 65 & 65 & MCG/L \\
\hline \multicolumn{4}{|l|}{ Minerals } \\
\hline Calcium & 669 & 656 & MG/L \\
\hline Chloride & 510 & 505 & MG/L \\
\hline Copper & 720 & 704 & MCG/L \\
\hline lodide & 123 & 112 & MCG/L \\
\hline Iron & 16 & 16 & MG/L \\
\hline Magnesium & 73 & 72 & MG/L \\
\hline Manganese & 177 & 162 & MCG/L \\
\hline Phosphorus & 376 & 378 & MG/L \\
\hline Potassium & 1117 & 1150 & MG/L \\
\hline Selenium & 31 & 31 & MCG/L \\
\hline Sodium & 288 & 286 & MG/L \\
\hline Zinc & 10 & 10 & MG/L \\
\hline
\end{tabular}

Table 1: Approximate nutrient contents of formula interventions. 
study formulas met levels of nutrients for infant formulas that were recommended by the American Academy of Pediatrics Committee on Nutrition and that are regulated by the Infant Formula Act of 1980 [21] and subsequent amendments [22].

Sufficient quantities of the study formulas were provided at each study visit (DOL $\leq 14,30,60,90$ and 120$)$ to enable parents to feed the assigned study product ad libitum as the sole source of nutrition for the duration of the study. Parents were given intake and tolerance forms to complete for three 24-hour periods prior to DOL 30 and 120 visits. Parents were asked to log the time and amount of formula taken. They were also asked to respond "yes" or "no" to the following tolerance questions: (1) Were your baby's stools watery? (2) Were your baby's stools hard? (3) Was your baby gassy? (4) Did your baby spit up more than usual after the feedings? (5) Was your baby fussy? (6) Are you satisfied with the formula?

\section{Outcomes}

Anthropometric assessments were made at each visit that included weight, length, weight/length ratio, and head circumference. All parents consented to have a blood sample collected from their infant at DOL 120 that evaluated red blood cell (RBC) fatty acids (DHA, ARA, EPA and DPAn-6), metabolic panel (sodium, potassium, chloride, carbon dioxide $\left[\mathrm{CO}_{2}\right]$, blood urea nitrogen, glucose, creatinine, and calcium). Consecutive subjects were enrolled in the blood collection sub-study until the target number of 72 had been reached ( 71 of the 72 subjects were able to provide blood). The recording of adverse events (coded by MedDRA 17.0) started after the parent signed the informed consent form and the subject was given the first feeding with study formula and continued until study completion.

\section{Statistical methods}

Rate of weight gain (gram/day) was calculated from the weight measured at enrollment subtracted from the weight measured at a subsequent visit, divided by the number of days between the actual visits. The $90 \%$ confidence interval approach of the "two one-sided test" (TOST) methodology was used to assess equivalence between the formulas. Study success and equivalence were established if the $90 \%$ confidence interval for the difference between groups in the daily weight gain was contained within the interval (-3.4 to 3.4) [23]. Further, a comprehensive assessment of the effects of gender on the primary endpoint was completed. For assessment of the effects of gender, two methodological approaches were summarized; 1) gender-stratified TOSTs were calculated to assess equivalence within genders, and 2) ANOVA methods with gain as the dependent variable, and with the treatment group, site and gender as factors in the model.

Continuous variables were summarized with the mean, standard deviation, median and range and were analyzed by analysis of covariance (ANOVA) or Wilcoxon rank sum tests, as appropriate. Categorical variables were analyzed by exact tests, chi-square tests or Cochran-Mantel-Haenszel tests, as appropriate. Results were considered statistically significant at the 5\% level. SAS (version 9.4) general linear model (GLM) and/or MIXED procedures were used for models and group comparisons on continuous endpoints. Categorical variables were summarized with counts and percentages and SAS FREQ procedure was used for group comparisons on categorical endpoints.

RBC fatty acid levels were calculated as weight percent of fatty acid, and as microgram of fatty acid per milliliter of red blood cells. These were analyzed using ANOVA with treatment group and site as factors in the model. Measures of bioequivalence of the RBC DHA blood levels $(\mu \mathrm{g} / \mathrm{mL})$ between the two groups were conducted by examining:

- If the difference between the group means of the logtransformed data was within -0.2231 and $+0.2231(+/-\ln (1.25))$, and

- If the ratio of the geometric means of the investigational formula compared to the standard control formula was within $80 \%$ and $125 \%$.

Determination of sample size was based on the assumption there was no difference between groups in daily weight gain. The overall standard deviation in daily weight gain was assumed $6 \mathrm{gram} /$ day, and therefore 55 subjects per group were required to be $80 \%$ sure that the $90 \%$ confidence interval for the difference was within the interval $(-3.4$ to 3.4) [23]. Originally, based on an estimated $25 \%$ attrition, enrollment of 144 infants was planned (72 per treatment group (36 male and 36 female) for the study. As attrition rose, an estimated $30 \%$ attrition rate was used to increase the sample size by 15 subjects to a total of 159 . This led to approximately 79 subjects in each group with approximately 39 of each gender.

\section{Results}

Subject (infant) disposition is shown in Figure 1. There were no screen failures. Overall, 159 infants were randomized into the study (79 in the DHASCO ${ }^{\circledR}$ group; 80 in the DHASCO ${ }^{\circledR}$-B group); 104 (65.4\%) completed the study. Of the 55 discontinued infants, 31 were withdrawn by the parent or investigator due to a treatment-emergent adverse event (TEAE) or serious adverse event (SAE), 11 were discontinued by the parent or investigator for reasons other than safety, 13 were lost to follow-up, and 1 was withdrawn for protocol non-compliance. Rate of discontinuation was $36 \%$ at Visit $1,31 \%$ at Visit $2,18 \%$ at Visit 3 and $14 \%$ at Visit 4.

Table 2 shows that demographic and baseline characteristics were similar between the 2 treatment groups. Overall, mean age $( \pm S D)$ of the infants at enrollment was $7.8 \pm 3.88$ days; the gender ratio was 81 (50.9\%) female and 78 (49.1\%) male; mean weight at enrollment was $3387.6 \pm 428.82 \mathrm{~g}$; and the majority of infants were white $(81.1 \%)$. Overall, $52.2 \%$ of mothers used prenatal DHA supplements, and a total of 31 (19.5\%) infants were fed breast milk prior to enrollment. Body weight, length and head circumference at enrollment were similar between the 2 groups; the overall mean $( \pm S D)$ totals were 3387.6 grams $( \pm 428.82), 50.6 \mathrm{~cm}( \pm 2.17)$ and $35.0 \mathrm{~cm}( \pm 1.48)$, respectively. There was greater than $75 \%$ mean compliance in both treatment groups as assessed by counting the number of bottles of formulae returned at the last visit.

Infants in the 2 groups were similar in terms of rate of weight increase from Day 14 to Days 30, 60, 90, and $120(36.5 \pm 11.54 \mathrm{~g} /$ day in the reference group vs. $33.5 \pm 10.40 \mathrm{~g} /$ day in the $\mathrm{DHASCO}^{\circledR}$ - $\mathrm{B}$ group at Day $30 ; 32.8 \pm 8.42 \mathrm{~g} /$ day in the reference group vs. $32.8 \pm 9.81 \mathrm{~g} /$ day in the DHASCO ${ }^{\circledR}$-B group at Day $60 ; 30.5 \pm 7.53 \mathrm{~g} /$ day in the reference group vs. $31.2 \pm 8.92 \mathrm{~g} /$ day in the DHASCO ${ }^{\circledR}-\mathrm{B}$ group at Day 90 ; and $29.1 \pm 5.92 \mathrm{~g} /$ day in the reference group vs. $29.9 \pm 7.40 \mathrm{~g} /$ day in the DHASCO $^{\circ}$-B group at Day 120 ). There was also no difference between treatment groups in actual weight gain over time, i.e. at enrollment, DOL 30, 60, 90 and 120 using repeated measures ANOVA ( $\mathrm{p}=0.252)$.

The similarities in growth rate were reflected in similarities in achieved body weight (Figure 2). For the primary endpoint, the rates of mean daily weight gain $( \pm S D)$ by DOL 120 were equivalent between the formulas $(90 \%$ CI TOST: -2.94 to 1.31 , within the equivalence 
Citation: Mehta P, Shepard J, Rouse K, Sullivan T, McCarthy D, et al. (2016) Growth and Tolerability of Healthy Term Infants Fed a New Formula Supplemented with DHA from Schizochytrium sp Microalgae. J Vasc Med Surg 4: 267. doi:10.4172/2329-6925.1000267

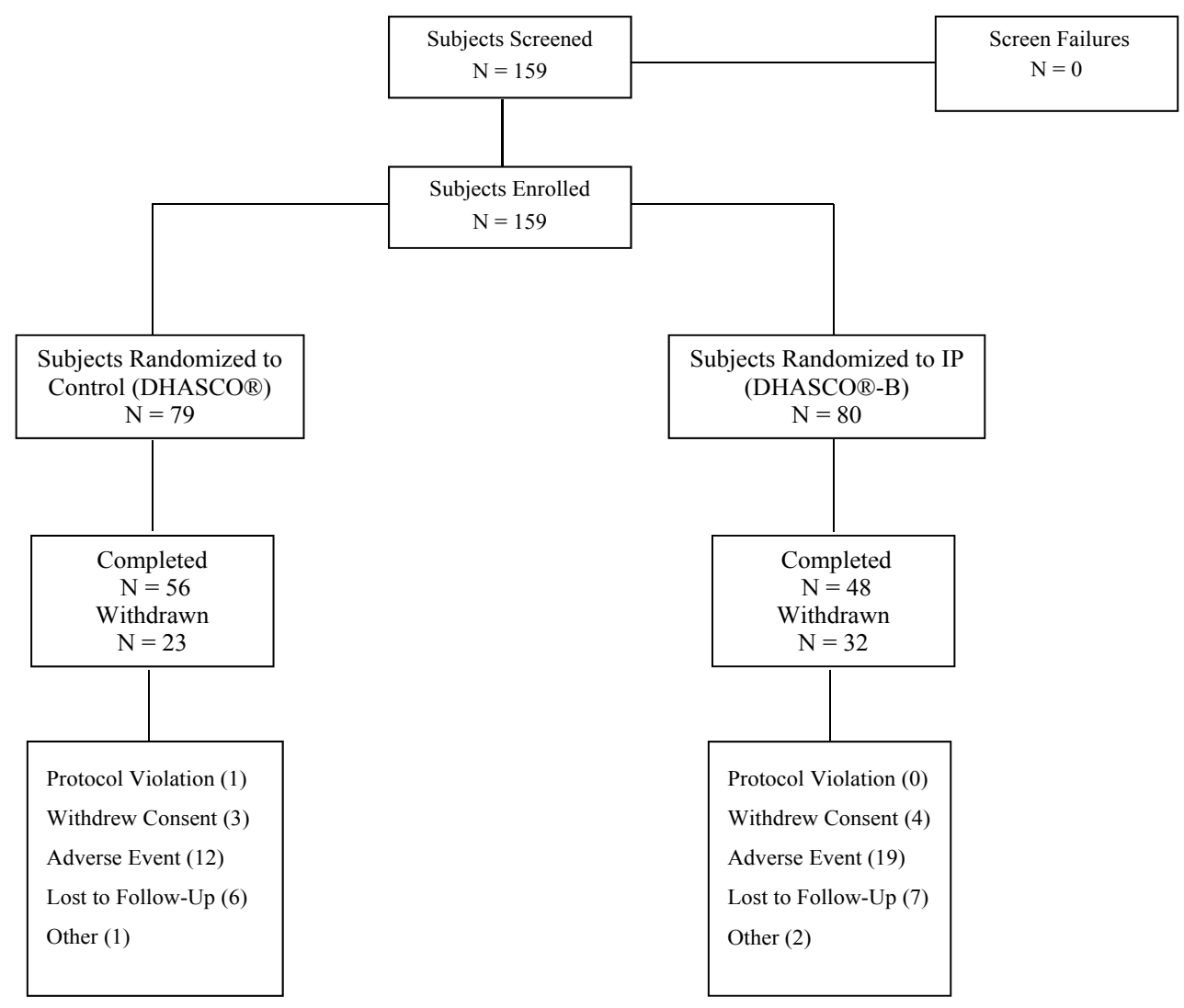

Figure 1: Subject (infant) Disposition.

\begin{tabular}{|c|c|c|c|c|}
\hline Characteristic & DHASCO $\otimes(n=79)$ & DHASCO $\otimes-B(n=80)$ & All Subjects $(n=159)$ & P-Value $^{1}$ \\
\hline \multicolumn{5}{|l|}{ Age (days) } \\
\hline $\mathrm{N}$ & 79 & 80 & 159 & 0.627 \\
\hline Mean \pm SD & $7.9 \pm 3.90$ & $7.6 \pm 3.87$ & $7.8 \pm 3.88$ & \\
\hline Range & 2.0 to 14.0 & 0.0 to 14.0 & 0.0 to 14.0 & \\
\hline Median & 7 & 7 & 7 & \\
\hline \multicolumn{5}{|l|}{ Gender } \\
\hline Female & $40(50.6 \%)$ & $41(51.3 \%)$ & $81(50.9 \%)$ & 0.938 \\
\hline Male & $39(49.4 \%)$ & $39(48.8 \%)$ & $78(49.1 \%)$ & \\
\hline \multicolumn{5}{|l|}{ Ethnicity } \\
\hline Hispanic or Latino & $2(2.5 \%)$ & $11(13.8 \%)$ & $13(8.2 \%)$ & 0.01 \\
\hline Not Hispanic or Latino & $77(97.5 \%)$ & $69(86.3 \%)$ & $146(91.8 \%)$ & \\
\hline \multicolumn{5}{|l|}{ Race $^{2}$} \\
\hline American Indian or Alaskan Native & $1(1.3 \%)$ & $2(2.5 \%)$ & $3(1.9 \%)$ & 1 \\
\hline Asian & $0(0.0 \%)$ & $1(1.3 \%)$ & $1(0.6 \%)$ & 1 \\
\hline Black or African American & $17(21.5 \%)$ & $20(25.0 \%)$ & $37(23.3 \%)$ & 0.603 \\
\hline Native Hawaiian or Other Pacific Islander & $0(0.0 \%)$ & $1(1.3 \%)$ & $1(0.6 \%)$ & 1 \\
\hline White & $66(83.5 \%)$ & $63(78.8 \%)$ & $129(81.1 \%)$ & 0.44 \\
\hline \multicolumn{5}{|l|}{ Prenatal DHA used } \\
\hline No & $26(32.9 \%)$ & $19(23.8 \%)$ & $45(28.3 \%)$ & 0.068 \\
\hline Yes & $34(43.0 \%)$ & $49(61.3 \%)$ & $83(52.2 \%)$ & \\
\hline Unknown & $19(24.1 \%)$ & $12(15.0 \%)$ & $31(19.5 \%)$ & \\
\hline \multicolumn{5}{|l|}{ Weight (gram) } \\
\hline $\mathrm{N}$ & 79 & 80 & 159 & 0.249 \\
\hline Mean \pm SD & $3430.1 \pm 419.83$ & $3345.5 \pm 436.06$ & $3387.6 \pm 428.82$ & \\
\hline Range & 2495.0 to 4330.0 & 2322.0 to 4547.0 & 2322.0 to 4547.0 & \\
\hline Median & 3362.5 & 3344.3 & 3346 & \\
\hline
\end{tabular}


Citation: Mehta P, Shepard J, Rouse K, Sullivan T, McCarthy D, et al. (2016) Growth and Tolerability of Healthy Term Infants Fed a New Formula Supplemented with DHA from Schizochytrium sp Microalgae. J Vasc Med Surg 4: 267. doi:10.4172/2329-6925.1000267

Page 5 of 9

\begin{tabular}{|c|c|c|c|c|}
\hline \multicolumn{5}{|l|}{ Length $(\mathrm{cm})$} \\
\hline $\mathrm{N}$ & 79 & 80 & 159 & 0.162 \\
\hline Mean \pm SD & $50.8 \pm 2.23$ & $50.3 \pm 2.09$ & $50.6 \pm 2.17$ & \\
\hline Range & 45.2 to 54.8 & 43.7 to 54.6 & 43.7 to 54.8 & \\
\hline Median & 50.9 & 50.3 & 50.5 & \\
\hline \multicolumn{5}{|c|}{ Head Circumference $(\mathrm{cm})$} \\
\hline$N$ & 79 & 80 & 159 & 0.181 \\
\hline Mean \pm SD & $35.2 \pm 1.42$ & $34.8 \pm 1.52$ & $35.0 \pm 1.48$ & \\
\hline Range & 31.2 to 37.5 & 29.0 to 38.1 & 29.0 to 38.1 & \\
\hline Median & 35.3 & 35 & 35.1 & \\
\hline
\end{tabular}

Table 2: Demographics and Baseline Characteristics (Safety Population). 'Birth anthropometrics (weight, length and head circumference) were analyzed using analysis of variance (ANOVA) methods with treatment group and gender as factors in the model. Age at enrollment was analyzed using ANOVA methods with treatment group as a factor in the model. Gender, ethnicity, mother use of prenatal vitamins, and race were analyzed by exact tests, chi-square tests or Cochran-Mantel-Haenszel statistics, as appropriate, to compare the treatment groups on these demographic variables. If an endpoint was measured in duplicate, then the average of the two assessments was used as the measurement for that visit. ${ }^{2}$ The parents were permitted to choose more than one race.

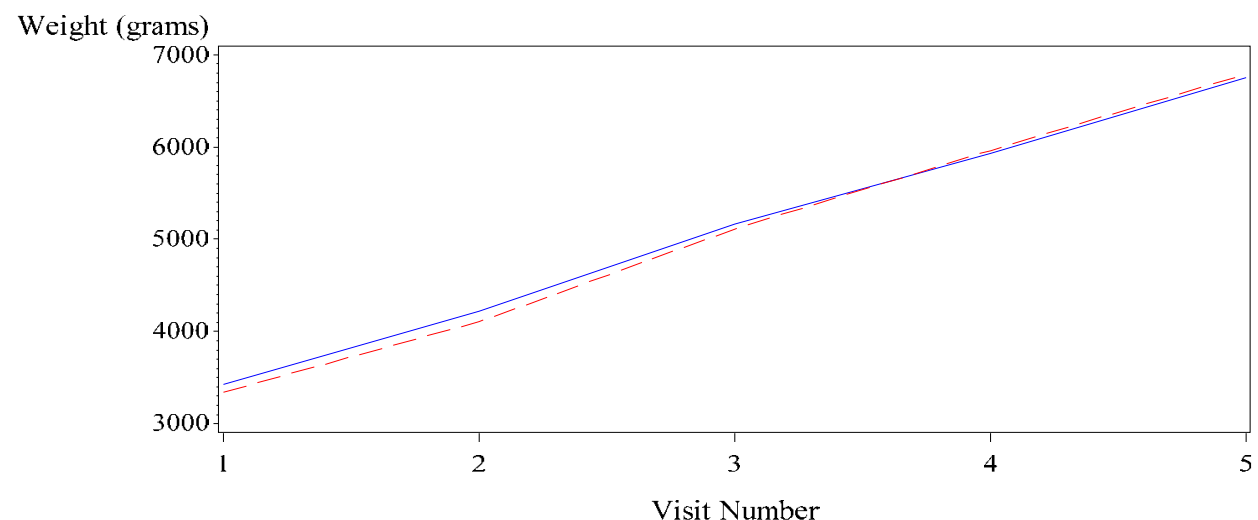

Visit Number

Treatment - DHASCO DHASCO-B

\begin{tabular}{|c|c|c|c|c|}
\hline $\begin{array}{l}\text { Visit } \\
\text { (DOL) }\end{array}$ & Statistic & $\begin{array}{c}\text { DHASCO } \\
(n=79)\end{array}$ & $\begin{array}{c}\text { DHASCO-B } \\
(n=80)\end{array}$ & p-Value \\
\hline \multicolumn{5}{|l|}{ Weight (grams) } \\
\hline Visit 1 & $\mathrm{~N}$ & 79 & 80 & \\
\hline \multirow[t]{3}{*}{$(\mathrm{DOL} \leq 14)$} & Mean \pm SD & $3430.1 \pm 419.83$ & $3345.5 \pm 436.06$ & \\
\hline & Range & 2495.0 to 4330.0 & 2322.0 to 4547.0 & \\
\hline & Median & 3362.5 & 3344.3 & \\
\hline Visit 5 & $\mathrm{~N}$ & 57 & 52 & \\
\hline \multirow[t]{3}{*}{ (DOL 120) } & Mean \pm SD & $6750.9 \pm 853.97$ & $6789.5 \pm 818.51$ & \\
\hline & Range & 5360.0 to 9392.5 & 4910.5 to 9170.0 & \\
\hline & Median & 6803.0 & 6696.3 & \\
\hline Weight Gain (grams/day) & $\mathrm{N}$ & 57 & 52 & \\
\hline \multirow[t]{3}{*}{ Visit 1 to Visit 5} & Mean \pm SD & $29.1 \pm 5.92$ & $29.9 \pm 7.40$ & $0.553[1]$ \\
\hline & Range & 16.4 to 45.0 & 14.1 to 51.2 & $0.252[2]$ \\
\hline & Median & 29.2 & 29.2 & \\
\hline $90 \% \mathrm{Cl}$ TOST [3] & \multicolumn{4}{|c|}{-2.94 to $1.31:$ Equivalent } \\
\hline \multicolumn{5}{|c|}{$\begin{array}{l}\text { [1] P-value for Visit } 5 \text { Gain using analysis of variance (ANOVA) methods with gain as the dependent variable, and } \\
\text { with treatment group, site and gender as factors in the model. } \\
\text { [2] P-value for actual measurements at enrollment } \mathrm{DOL} 30,60,90 \text { and } 120 \text { using repeated measures analysis of } \\
\text { variance (ANOVA) with time, treatment group, site, gender and the interaction as factors in the model. } \\
\text { [3] The } 90 \% \text { confidence interval (CI) approach of the two one-sided test (TOST) methodology. Study success and } \\
\text { equivalence was established if the } 90 \% \mathrm{Cl} \text { for the difference between groups in the daily weight gain was } \\
\text { contained within the interval (-3.4 to 3.4). }\end{array}$} \\
\hline
\end{tabular}

Figure 2: Random Slopes Growth Curves and Rate of Weight Gain.

interval -3.4 to 3.4). Using ANOVA methods, with daily weight gain as the dependent variable, and with treatment group, site and gender as factors in the model, there was no significant difference in rate of weight gain between the treatment groups $(29.1 \pm 5.92$ grams/ day versus $29.9 \pm 7.40$ grams/day for DHASCO $^{\circledR}$ and DHASCO $^{\circledR}-\mathrm{B}$, respectively; $\mathrm{p}=0.553$ ). 
Citation: Mehta P, Shepard J, Rouse K, Sullivan T, McCarthy D, et al. (2016) Growth and Tolerability of Healthy Term Infants Fed a New Formula Supplemented with DHA from Schizochytrium sp Microalgae. J Vasc Med Surg 4: 267. doi:10.4172/2329-6925.1000267

Page 6 of 9

Overall, as expected, males were heavier at baseline and throughout the study (Figure 3). While both males and females had a pattern of slightly greater weight gain in the early visits with the reference formula, this trend was reversed in later visits for females in which equivalence was established between treatment groups (90\% CI TOST: -3.38 to 1.76$)$. Males, on the other hand, had a small early greater weight gain with the reference formula that resulted in nonequivalence (90\% CI TOST: -3.72 to 2.32 ). However, in the per protocol population of subjects who completed the study, daily weight gain was equivalent for males (90\% CI TOST: -3.38 to 3.08 ).

The mean $( \pm \mathrm{SD})$ rates of daily length gain and head circumference gain by DOL 120 were not different for the reference and DHASCO ${ }^{\mathbb{B}}$-B formula groups $(0.1 \pm 0.01 \mathrm{~cm} /$ day for both measures; $\mathrm{p}=0.992$ and $\mathrm{p}=0.223$, respectively). Actual measurements over time also showed no significant difference in length gain or head circumference gain between the formulas $(\mathrm{p}=0.128$ and $\mathrm{p}=0.299$, respectively). Daily ratio (weight/ length) gain by DOL 120 was not significant between the formula groups, $0.3 \pm 0.09$ and $0.4 \pm 0.11$, for the reference and $\mathrm{DHASCO}^{\circledR}-\mathrm{B}$ groups, respectively ( $\mathrm{p}=0.485$ ), and analysis of assessments over time also showed no difference in ratio gain between formula groups $(\mathrm{p}=0.335)$.

Tolerance evaluation showed no difference between formula groups in any of the following variables at either DOL 30 or 120: watery stools, hard stools, gassiness, spitting up or fussiness. The most common tolerance issue was gassiness (flatulence) at Day 30 ( $72.2 \%$ vs. $63.8 \%$ for reference vs. DHASCO ${ }^{\circ}-\mathrm{B}$, respectively; $\left.\mathrm{p}=0.538\right)$, and Day $120(29.1 \%$ vs. $32.5 \%$, respectively; $\mathrm{p}=0.312$ ). At Day $30,79.7 \%$ vs. $72.5 \%$ of parents (reference vs. DHASCO $^{\circ}-\mathrm{B}, \mathrm{p}=0.520$ ) reported satisfaction; and at Day $120,63.3 \%$ vs. $58.8 \%$ of parents (reference vs. DHASCO $^{\circledR}-\mathrm{B}, \mathrm{p}=1.000$ ) reported satisfaction with the formulas.

Fatty acid profiles in red blood cells generally reflected the

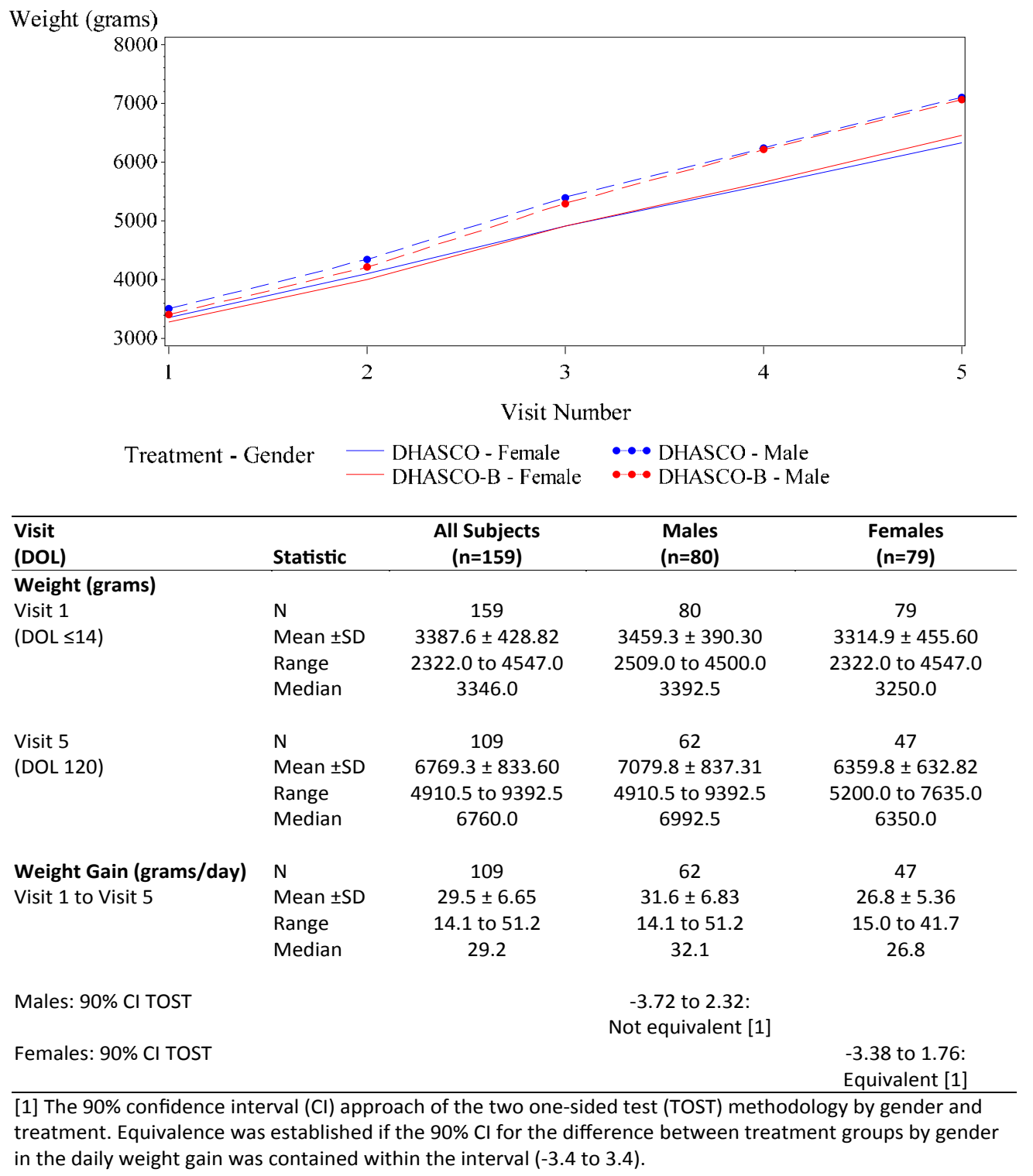

Figure 3: Random Slopes Growth Curves and Rate of Weight Gain by Gender. 
Citation: Mehta P, Shepard J, Rouse K, Sullivan T, McCarthy D, et al. (2016) Growth and Tolerability of Healthy Term Infants Fed a New Formula Supplemented with DHA from Schizochytrium sp Microalgae. J Vasc Med Surg 4: 267. doi:10.4172/2329-6925.1000267

composition of the oils in the two formulas (Table 3). Measures of bioequivalence of the DHA red blood cell levels between the reference $(1.29 \mu \mathrm{g} / \mathrm{mL})$ and $\mathrm{DHASCO}^{\circ}-\mathrm{B}(1.33 \mu \mathrm{g} / \mathrm{mL})$ formulas were achieved. The difference between the group means of the log-transformed DHA data was -0.04198 (within -0.2231 and $+0.2231[+/-\ln (1.25)]$ ), and the ratio of the geometric means for DHA with the DHASCO ${ }^{\circledR}$-B formula relative to the reference formula was $96.85 \%$ (within $80 \%$ and $125 \%$ ). Total formula intake between the DHASCO ${ }^{\circ}$-B and reference groups did not vary significantly at DOL 30 (76.0 vs. 80.8 ounces; $n=59$ and $\mathrm{n}=66$, respectively; $\mathrm{p}=0.256$ ) or at DOL 120 (median: 105.5 ounces vs. 105.0 ounces; $n=43$ and $n=47$, respectively; $p=0.834$ ).

Treatment-emergent adverse events are summarized overall and for individual incidence $\geq 5 \%$ with either formula in Table 4 . The overall incidence of TEAEs was slightly greater with DHASCO $^{\circledR}-\mathrm{B}$ than with the reference formula ( $72.5 \%$ and $57.0 \%$, respectively). The frequency of SAEs was low, 7 subjects in the DHASCO ${ }^{\circ}$-B group (viral infection in 4 subjects, sleep apnea in 1 subject, gastric obstruction in 1 subject and sudden infant death syndrome in 1 subject) and 2 subjects in the $\mathrm{DHASCO}^{\circ}$ group (urinary tract infection and bronchiolitis). All SAEs were considered not related to study formula and all but one had resolved by the end of the study. The death from sudden infant death syndrome occurred approximately 3 months after the first intake of formula and was considered by the investigator as unrelated to treatment. As shown in Table 3, the incidence of infants who experienced a TEAE assessed with a definite $(7.5 \%$ vs. $7.6 \%$, respectively) or suspected ( $18.8 \%$ vs. $15.2 \%$, respectively) relationship to product was similar among the 2 groups. Consistent with tolerance assessments, flatulence had the highest incidence among all subjects (21.3\% DHASCO-B vs. $11.4 \%$ DHASCO, respectively). Other events were generally comparable between the formulas, and as expected gastrointestinal events were more prevalent than other TEAEs.

\begin{tabular}{|c|c|c|c|c|}
\hline $\begin{array}{c}\text { Microgram of Fatty Acid per ml } \\
\text { of RBC }\end{array}$ & DHASCO $®(n=33)$ & DHASCO®-B (n=36) & $\begin{array}{l}\text { All Subjects } \\
(n=69)\end{array}$ & P-value ${ }^{1}$ \\
\hline \multicolumn{5}{|c|}{$\mathrm{DHA}$} \\
\hline Mean \pm SD & $56.8 \pm 20.82$ & $59.0 \pm 17.43$ & $58.0 \pm 19.01$ & 0.741 \\
\hline Range & 14.6 to 100.1 & 10.5 to 84.3 & 10.5 to 100.1 & \\
\hline Median & 59.5 & 61.4 & 59.5 & \\
\hline \multicolumn{5}{|c|}{ EPA } \\
\hline Mean \pm SD & $1.5 \pm 0.50$ & $2.9 \pm 0.93$ & $2.3 \pm 1.03$ & $<.001$ \\
\hline Range & 0.5 to 3.0 & 1.0 to 5.1 & 0.5 to 5.1 & \\
\hline Median & 1.5 & 3.1 & 2.0 & \\
\hline \multicolumn{5}{|c|}{ DPAn-6 } \\
\hline Mean \pm SD & $3.6 \pm 1.37$ & $4.8 \pm 1.54$ & $4.2 \pm 1.58$ & 0.002 \\
\hline Range & 0.0 to 6.6 & 1.0 to 8.2 & 0.0 to 8.2 & \\
\hline Median & 3.7 & 4.8 & 4.3 & \\
\hline \multicolumn{5}{|c|}{ ARA } \\
\hline Mean \pm SD & $175.9 \pm 52.46$ & $180.6 \pm 44.42$ & $178.4 \pm 48.13$ & 0.919 \\
\hline Range & 40.3 to 271.8 & 45.7 to 236.5 & 40.3 to 271.8 & \\
\hline Median & 187.7 & 187.2 & 187.7 & \\
\hline
\end{tabular}

Table 3: Red Blood Cell (RBC) Fatty Acids: DHA, EPA, DPAn-6 and ARA.

\begin{tabular}{|c|c|c|c|}
\hline & $\begin{array}{c}\text { DHASCO } \\
(n=79)\end{array}$ & $\begin{array}{l}\text { DHASCO®-B } \\
\quad(n=80)\end{array}$ & $\begin{array}{c}\text { All Subjects } \\
\quad(n=159)\end{array}$ \\
\hline Any Adverse Event (AE) & $45(57.0 \%)$ & $58(72.5 \%)$ & $103(64.8 \%)$ \\
\hline Any Serious $A E$ & $2(2.5 \%)$ & $7(8.8 \%)$ & $9(5.7 \%)$ \\
\hline \multicolumn{4}{|c|}{ Any Related $\mathrm{AE}^{1}$} \\
\hline Suspected & $12(15.2 \%)$ & $15(18.8 \%)$ & $27(17.0 \%)$ \\
\hline Definite & $6(7.6 \%)$ & $6(7.5 \%)$ & $12(7.5 \%)$ \\
\hline \multicolumn{4}{|c|}{ Individual AEs ${ }^{2}$} \\
\hline Flatulence & $9(11.4 \%)$ & $17(21.3 \%)$ & $26(16.4 \%)$ \\
\hline Upper respiratory tract infection & $11(13.9 \%)$ & $13(16.3 \%)$ & $24(15.1 \%)$ \\
\hline Gastroesophageal reflux disease & $11(13.9 \%)$ & $12(15.0 \%)$ & $23(14.5 \%)$ \\
\hline Constipation & $4(5.1 \%)$ & $7(8.8 \%)$ & $11(6.9 \%)$ \\
\hline Irritability & $3(3.8 \%)$ & $7(8.8 \%)$ & $10(6.3 \%)$ \\
\hline Viral infection & $2(2.5 \%)$ & $7(8.8 \%)$ & $9(5.7 \%)$ \\
\hline Abdominal pain & $6(7.6 \%)$ & $5(6.3 \%)$ & $11(6.9 \%)$ \\
\hline Bronchiolitis & $5(6.3 \%)$ & $3(3.8 \%)$ & $8(5 \%)$ \\
\hline Vomiting & $5(6.3 \%)$ & $3(3.8 \%)$ & $8(5 \%)$ \\
\hline Cough & $2(2.5 \%)$ & $5(6.3 \%)$ & $7(4.4 \%)$ \\
\hline Diarrhoea & $4(5.1 \%)$ & $3(3.8 \%)$ & $7(4.4 \%)$ \\
\hline
\end{tabular}

${ }^{1}$ Suspected: there was a reasonable possibility that the investigational product caused the event. Definite: the event was temporally related to the administration of the investigational product and no other etiology explained the event.

${ }^{2} \mathrm{AEs}$ are ranked from highest to lowest incidence for any treatment group; if a subject experienced the same event more than once, only the first occurrence was tabulated.

Table 4: Overall and Individual Incidence of Adverse Events ( $\geq 5 \%$ with either Formula). 
Citation: Mehta P, Shepard J, Rouse K, Sullivan T, McCarthy D, et al. (2016) Growth and Tolerability of Healthy Term Infants Fed a New Formula Supplemented with DHA from Schizochytrium sp Microalgae. J Vasc Med Surg 4: 267. doi:10.4172/2329-6925.1000267

Page 8 of 9

\section{Discussion}

LCPUFAs are essential nutrients for optimal brain and retinal development and infant growth [3-9,24,25]. Studies have shown the growth of infants fed LCPUFA-supplemented formulas do not differ significantly from breast-milk feeding, and the supplemented formulas are well tolerated [10,26-29]. Further, supplementation of DHA and ARA from single cell algal and fungal sources in term infants (at recommended worldwide human milk levels) results in RBC concentrations of the LCPUFAs, which are comparable to those of breast-fed infants [19,30-32]. The present study confirmed that a new infant formula (DHASCO ${ }^{\circ}$-B) supplemented with DHA from a unique strain of Schizochytrium sp microalgae promoted growth according to WHO growth standards [20], and in an equivalent manner to a standard reference formula $\left(\mathrm{DHASCO}^{\circledR}\right)$ [15].

Both formulas (DHASCO ${ }^{\circledR}-\mathrm{B}$ and $\mathrm{DHASCO}^{\circledR}$ ) are GRAS when incorporated in infant formula at a maximum use level of $1.25 \%$ of dietary fat $[15,18]$. This level corresponds to a maximum of $0.5 \%$ of total fat as DHA. Assuming human infants consume about 100 to $120 \mathrm{kcal} / \mathrm{kg}$ body wt/day, of which fat comprises about $50 \%$, an infant will consume about $50-60 \mathrm{kcal} / \mathrm{kg}$ body wt/day of fat, or about 5.5-6.7 $\mathrm{g}$ of fat $/ \mathrm{kg}$ body wt $/$ day $(1 \mathrm{~g}$ fat $=9 \mathrm{kcal})$. The $\mathrm{DHASCO}^{\circledR}-\mathrm{B}$ formula maximum intake of $1.25 \%$ of daily fat for an infant would correspond to $69-83 \mathrm{mg}$ DHASCO ${ }^{\circledR}-\mathrm{B} / \mathrm{kg}$ body wt/day providing 27 $33 \mathrm{mg} / \mathrm{kg}$ body wt/day of DHA which is consistent with current DHA recommendations for term and preterm infants of 10-60 DHA mg/ $\mathrm{kg}$ body weight depending on gestational age [33]. DHASCO ${ }^{\circledR}-\mathrm{B}$ is intended to be used in combination with a source of arachidonic acid (ARA) when added to pre-term, term, and follow on infant formulas. The ratio of DHA to ARA typically ranges from 1:1 to 1:2.

The present study demonstrated equivalent growth profiles (gains in weight, body length and head circumference) across both formulas [20], as well as comparable tolerability. Bioequivalence of DHA levels in RBCs, representative of tissue levels, was also demonstrated with DHASCO $^{\circ}$-B compared to DHASCO ${ }^{\circledR}$. When analyzed by gender, females displayed equivalent weight gain across both formulas. While male infants tended to have a greater rate of weight gain in the reference group, the difference from the DHASCO ${ }^{\circledR}-\mathrm{B}$ group was not clinically meaningful. These results could be confounded by the fact that males are known to have greater rates of growth in the first 4 months of life [20]. The small sample size and statistical variability due to noncompleters likely contributed to the non-equivalent findings in males, as the study showed equivalence in the analysis of the male infants who completed the study per protocol.

Supplementation of term infant formula with $0.36 \%$ DHA and $0.72 \%$ ARA during the first year of life yields clear differences in total RBC lipid composition and in visual function [30]. By 17 weeks of age, DHA concentrations in RBCs from supplemented formulas will more than double, and by week 39 will be more than 3 times. In the current study, infants in both formula groups had an equivalent absorption of DHA that is consistent with other published trials $[5,8]$.

In conclusion, this trial demonstrated that at 4 months of life (120 days), there was no difference in daily weight gain between infants fed formula supplemented with DHASCO ${ }^{\circledR}$-B than those fed with standard formula containing $\mathrm{DHASCO}^{\circledR}$ and the overall weight gains were found to be equivalent between the two formulas. Length gain, head circumference gain and ratio (weight/length) gain were also equivalent. The RBC levels of DHA were bioequivalent between the two formula groups and consistent with commercial supplemented formulas.
Tolerability was not significantly different between formula groups, nor was parent satisfaction different between the formulas. Overall, safety profiles for the formulas were similar and typical for this age group and did not raise any concerns.

\section{Acknowledgement}

We acknowledge the following investigators for their invaluable contributions: Dr. Amy Aqua, Dr. Jeffrey Hirschfield, Dr. Richard Litov, Dr. Stephen Russell, Dr. Claude Ashley, and Dr. Stephen Kasparian. We thank Eileen Bailey-Hall for her contribution in analyzing the red blood cell fatty acids.

\section{References}

1. Salem N Jr, Litman B, Kim HY, Gawrisch K (2001) Mechanisms of action of docosahexaenoic acid in the nervous system. Lipids 36: 945-959.

2. Salem Jr N (1989) Omega-3 fatty acids: molecular and biochemical aspects. In Spiller GA, Scala J (eds.) New Protective Roles for Selected Nutrients. Alan R Liss Inc New York 109-228.

3. Tam EW, Chau V, Barkovich AJ, Ferriero DM, Miller SP, et al. (2016) Early postnatal docosahexaenoic acid levels and improved preterm brain development. Pediatr Res.

4. Carlson SE, Werkman SH, Rhodes PG, Tolley EA (1993) Visual-acuity development in healthy preterm infants: effect of marine-oil supplementation. Am J Clin Nutr 58: 35-42

5. Birch EE, Hoffman DR, Uauy R, Birch DG, Prestidge C (1998) Visual acuity and the essentiality of docosahexaenoic acid and arachidonic acid in the diet of term infants. Pediatr Res 44: 201-209.

6. Makrides M, Neumann M, Simmer K, Pater J, Gibson R (1995) Are long-chain polyunsaturated fatty acids essential nutrients in infancy? Lancet 345: 14631468.

7. Koletzko B, Cetin I, Brenna JT, Perinatal Lipid Intake Working Group; Child Health Foundation; Diabetic Pregnancy Study Group; European Association of Perinatal Medicine; European Association of Perinatal Medicine; European Society for Clinical Nutrition and Metabolism; European Society for Paediatric Gastroenterology, Hepatology and Nutrition, Committee on Nutrition; International Federation of Placenta Associations. International Society for the Study of Fatty Acids and Lipids (2007) Dietary fat intakes for pregnant and lactating women. Br J Nutr 98: 873-877.

8. Hoffman DR, Boettcher JA, Diersen-Schade DA (2009) Toward optimizing vision and cognition in term infants by dietary docosahexaenoic acid and arachidonic acid supplementation: a review of randomized controlled trials. Prostaglandins Leukot Essent Fatty Acids 81: 151-158.

9. Ryan AS, Zeller SG, Nelson EB (2010) Safety evaluation of single cell oils and the regulatory requirements for use as food ingredients. In: Cohen Z, Ratledge C (eds.) Single Cell Oils. AOCS Press Champaign Illinois 1: 317-350.

10. Fleith M, Clandinin MT (2005) Dietary PUFA for preterm and term infants: review of clinical studies. Crit Rev Food Sci Nutr 45: 205-229.

11. Martinez M (1991) Developmental profiles of polyunsaturated fatty acids in the brain of normal infants and patients with peroxisomal disease: severe deficiency of docosahexaenoic acid in Zellweger's and pseudo-Zellweger's syndromes. World Rev Nutr Diet 66: 87-102.

12. Brenna JT, Varamini B, Jensen RG, Diersen-Schade DA, Boettcher JA, et al. (2007) Docosahexaenoic and arachidonic acid concentrations in human breast milk worldwide. Am J Clin Nutr 85: 1457-1464

13. (2008) Joint FAO/WHO Expert Consultation on Fats and Fatty Acids in Human Nutrition. Interim Summary of Conclusions and Dietary Recommendations on Total Fat \& Fatty Acids.

14. Trahms CM, McKean KN (2007) Nutrition during infancy. In: Mahan LK, EscottStump S (eds.) Krause's Food \& Nutritional Therapy. Elsevier 1: 199-221.

15. (2001) Substances Affirmed as Generally Recognized as Safe: DHASCO (Docosahexaenoic Acid-Rich Single-Cell Oil) and ARASCO (Arachidonic AcidRich Single-Cell Oil)

16. (2003) Substances Affirmed as Generally Recognized as Safe: DHA-rich Algal Oil (Schizochytrium sp.). GRN No. 137, FDA.

17. Martek (2010) Expert Panel Report Concerning the Generally Recognized as Safe (GRAS) Status of Algal Oil derived from a New Production Strain of Schizochytrium sp. Martek Biosciences Corporation. 
Citation: Mehta P, Shepard J, Rouse K, Sullivan T, McCarthy D, et al. (2016) Growth and Tolerability of Healthy Term Infants Fed a New Formula Supplemented with DHA from Schizochytrium sp Microalgae. J Vasc Med Surg 4: 267. doi:10.4172/2329-6925.1000267

Page 9 of 9

18. (2015) Substances Affirmed as Generally Recognized as Safe: DHA-rich Algal Oil (Schizochytrium sp.). GRN No. 553, Food and Drug Administration.

19. Makrides M, Neumann MA, Byard RW, Simmer K, Gibson RA (1994) Fatty acid composition of brain, retina, and erythrocytes in breast- and formula-fed infants. Am J Clin Nutr 60: 189-194.

20. (2015) WHO Child Growth Standards Guidelines Growth velocity based on weight, length and head circumference. Methods and development.

21. (1980) Infant Formula Act of 1980.

22. (1986) Infant Formula: 21 Code of Federal Regulations (as amended) [412] Sect.

23. (2016) Clinical testing of infant formulas with respect to nutritional suitability for term infants. US Food and Drug Administration.

24. A SAS Program for the WHO Growth Charts (ages 0 to $<2$ years)

25. (2006) DHA and ARA and visual development - Scientific substantiation of a health claim related to docosahexaenoic acid (DHA) and arachidonic acid (ARA) and visual development pursuant to Article 14 of Regulation (EC) No 1924/2006[1]. European Food Safety Authority.

26. Campoy C, Escolano-Margarit MV, Anjos T, Szajewska H, Uauy R (2012) Omega 3 fatty acids on child growth, visual acuity and neurodevelopment. $\mathrm{Br}$ J Nutr 2: S85-106.

27. Collins CT, Makrides M, Gibson RA, McPhee AJ, Davis PG, et al. (2011) Pre- and post-term growth in pre-term infants supplemented with higher-dose DHA a randomised controlled trial. Br J Nutr 105: 1635-1643.

28. Fleddermann M, Demmelmair H, Grote V, Nikolic T, Trisic B, et al. (2014) Infant formula composition affects energetic efficiency for growth: the BeMIM study, a randomized controlled trial. Clin Nutr 33: 588-595.

29. Hoffman D, Ziegler E, Mitmesser SH, Harris CL, Diersen-Schade DA (2008) Soy-based infant formula supplemented with DHA and ARA supports growth and increases circulating levels of these fatty acids in infants. Lipids 43: 29-35.

30. Birch EE, Castañeda YS, Wheaton DH, Birch DG, Uauy RD, et al. (2005) Visual maturation of term infants fed long-chain polyunsaturated fatty acidsupplemented or control formula for 12 mo. Am J Clin Nutr 81: 871-879.

31. Gianni ML, Roggero P, Baudry C, Ligneul A, Morniroli D, et al. (2012)The influence of a formula supplemented with dairy lipids and plant oils on the erythrocyte membrane omega-3 fatty acid profile in healthy full-term infants: a double-blind randomized controlled trial. BMC Pediatr 12:164.

32. Miller MR, Seifert J, Szabo NJ, Clare-Salzler M, Rewers M, et al. (2010) Erythrocyte membrane fatty acid content in infants consuming formulas supplemented with docosahexaenoic acid (DHA) and arachidonic acid (ARA): an observational study. Matern Child Nutr 6: 338-346.

33. Koletzko B, Boey CC, Campoy C, Carlson SE, Chang N, et al. (2014) Current information and Asian perspectives on long-chain polyunsaturated fatty acids in pregnancy, lactation, and infancy: systematic review and practice recommendations from an early nutrition academy workshop. Ann Nutr Metab 65: 49-80 